\title{
Huntington's disease in two New Britain families
}

\author{
EUAN M SCRIMGEOUR
}

From the Department of Public Health, Rabaul, East New Britain, Papua New Guinea

SUMmary In East New Britain, Papua New Guinea, two Melanesian families were studied in which the typical features of Huntington's disease were observed in clinically affected members. Mendelian autosomal dominant inheritance was indicated by the respective family trees.

Huntington's disease is a genetically determined condition which conforms to the pattern of a Mendelian autosomal dominant trait. The gene is transmitted with full penetrance to males and females equally. ${ }^{1}$ The abnormal gene can also arise as a fresh mutation although this is a rare occurrence. ${ }^{2}$ The typical clinical presentation is one of the most striking in medicine. The patient, usually a young to middle aged adult, gradually develops involuntary movements which are more choreoathetoid than choreiform in nature and become widespread in many muscle groups. Characteristic features include Received for publication 4 October 1979 grimacing, dysarthria, odd postures and movements of the head, neck, and trunk, irregular respiratory movements, choreoathetosis of limbs and digits, and a lurching, dancing gait. Typically, increasing dementia becomes apparent and the disease progresses remorselessly over many years, resulting in ever increasing incapacitation. The usual cause of death is intercurrent infection. This is the first report of Huntington's disease in Papua New Guinea.

\section{Family studies}

The two family trees are illustrated in fig 1a and $b$. Mendelian autosomal dominant inheritance is clearly


FIG 1 (a) Family A pedigree, (b) family B pedigree. (All cases identified as being affected or neurologically abnormal were personally examined by the author.) 
indicated. Both families are Tolai, the predominant Melanesian group of the Gazelle Peninsula of East New Britain. In the families studied, evidence to indicate Huntington's disease has only been clearly shown in two generations in each case although presumptive cases span three or possibly four generations.

\section{Case reports}

\section{FAMILY A}

Subject III.5 was a female, unmarried, aged about 42 years. She is reported to have first developed involuntary movements about 10 years ago, and subsequently deterioration in behaviour and personality had been noted. Examination showed frequent grimacing, dysarthria, coarse choreoathetosis of limbs and digits, and an irregular, lurching gait. Evidence of cerebellar or pyramidal tract dysfunction was absent. She had marked dementia with memory loss, sparse conversation with perseveration, neglect of person, incontinence of urine, and emotional lability. Irritability and depression were usual and some paranoid thoughts were expressed. There was some difficulty in dressing yet, despite being totally blind as a result of trachoma, she lived alone and was well orientated in regard to person, time, and her immediate surroundings. This curious anomaly has been noted in other cases of this condition by Bruyn. ${ }^{3}$

Subject IV.10 was a female aged 11 years. She was reported to have been progressing normally until one year previously, when she was obliged to leave school because of strange behaviour and failing performance. On assessment she was inert, apathetic, and had little to say. She had an expressionless facies with some grimacing and repetitive sniffing. Vertical conjugate gaze was impaired. Unilateral shrugging was prominent but choreoathetoid movements were absent. Tremor was not present, and there was no hypertonia. Her movements were clumsy and gait was hesitant and faltering. A tendency to fall was reported. Epilepsy had not been noted.

Subject IV.12 was a female aged 4 years. After a normal birth and first year of infancy, she gradually became retarded with marked rigidity, hypertonia, and bradykinesia. She had a mask-like face with labial retraction, and ocular dyspraxia was prominent. Dystonic posturing was present. Epilepsy had not occurred. She died and was buried in a remote village and necropsy was refused.

\section{Family cases}

Subjects III.2 and III.11 are reported to have suffered from an illness closely resembling that now exhibited by subject III.5. Chronic choreoathetosis was present and both developed dementia before their deaths in middle age in 1970 and 1976, respectively. Subjects II.1 and II.3 are said to have died from the same affliction in middle life, before the First World War. Subject II.6 also died in middle age from a 'breathing disease'. It may be presumed that he carried the anomalous gene. Subject I.1 died on 15 October 1906 aged 'about 40 years', the cause of death not being recorded. Information about his wife, parents, or sibs is lacking. This man, or less likely his wife, may be presumed to have carried the gene for Huntington's disease.

\section{FAMILY B}

Subject III.17 was a male aged 28. Involuntary movements were first noted about 18 months previously. $\mathrm{He}$ had later resigned from his work as a mechanic. On examination he had an expressionless face with grimacing. Mild dysarthria was present. Vertical conjugate gaze was normal but rapid eye movements were impaired. Sparse choreoathetotic movements of limbs and digits, and a mildly ataxic gait were noted. There was no evidence of cerebellar or pyramidal tract dysfunction. His family reported that he had become depressed and withdrawn, but otherwise mental function appeared to be near normal.

Subject III.19 was a female aged 27. She reported the onset of involuntary movements about 2 years earlier. She had grimacing, dysarthria, and impairment of rapid eye movement. Some mimicral apraxia was noted. Sparse choreoathetotic movements of limbs and digits and lordotic movements of the trunk were present. Gait was ataxic and lurching. Cerebellar and pyramidal tract function were normal. She had early dementia with memory loss, some intellectual impairment, and had become facile. She was neglecting her domestic responsibilities and her husband had recently left her.

Subject III. 20 was a male aged 26. His illness had commenced about 3 years previously and he was the most severely affected patient in family $B$. The expression was vapid with prominent grimacing. Restriction of vertical conjugate gaze and impairment of rapid eye movements were present. Speech was markedly dysarthric with some grunting. A stereotyped movement was often visible which consisted of flexion of the neck accompanied by pursing of the lips, followed by neck extension with labial retraction. Mimicral apraxia was demonstrable. Unilateral shrugging and lordotic movements of the trunk, and sudden contractions of the diaphragm were striking. Choreoathetosis of limbs and digits and an ataxic, lurching, dancing gait were prominent. No evidence of cerebellar or pyramidal tract disease was noted. Dementia was present with memory loss, intellectual impairment, apathy, and deterioration in personal cleanliness. 
Subject III.22 was a female aged 23. Involuntary movements had first been noted about 3 years previously. She had grimacing, dysarthria, choreoathetosis of limbs and digits, and an ataxic dancing gait. Early dementia was obvious and she reacted inappropriately by giggling and clowning during assessment.

Subject III.23 was a male aged 19. On assessment sporadic grimacing was noted. Some impairment of rapid eye movements was noted. Dysarthria was not noted and choreoathetotic movements were not observed. Gait was normal and there appeared to be no impairment of mental function.

\section{Family cases}

Subjects II. 2 and II. 5 were reported by their surviving spouses to have suffered from an illness similar to that now exhibited by subjects II.17, 19, 20, and 22 . Chronic choreoathetosis with ataxia and terminal dementia were salient features. Despite exhaustive inquiries, no information regarding the cause of death of subject I.1 has been obtained although he was believed to have died in middle age. His wife subsequently had refused to divulge any information regarding her late husband's genealogy or relations. This lady remarried and lived to an advanced age. Her family tree has been examined and no case suggestive of Huntington's disease has been observed.

\section{Discussion}

It seems likely that the two families had a common ancestor. Subject I.1 of family B is believed to have been born in the village where subject I.1 of family $A$ lived. A clear relationship between these two males has not been defined although it is generally believed by members of both families that subject I.1 of family B was a half-brother or cousin of the children of subject I.1 of family A.

Estimates of the age at which evidence of the onset of the disease was first noted can only be approximate in this society where people usually do not know when they were born. In regard to the nine adults whose ages can be estimated with some degree of accuracy, the average reported age of onset was 28 years. The mean age of onset in large series varies from $35 \cdot 5$ to $43 \cdot 2$ years, although in Venezuela it was only 23 years. ${ }^{4-6}$

The approximate duration of clinical illness which can only be estimated in four adults in this series was 12.5 years. In other series mean duration varied from 10.5 to 16 years. ${ }^{5} 7$ The estimated average age at death of these four cases was 42.5 years as compared with 55 years in other large series. ${ }^{8}$

The diagnosis of Huntington's disease in these two families is supported by the classical clinical presentation of chronic choreoathetosis starting in early to middle adult life, accompanied by progressive dementia, and the typical family trees indicating Mendelian autosomal dominant inheritance. Sydenham's chorea occurs sporadically in association with rheumatic fever and the involuntary movements are more choreiform. There was no evidence to suggest Wilson's disease in these patients. Kayser-Fleischer rings and evidence of liver disease were not present. Rigidity and tremor are more characteristic of Wilson's disease than is choreoathetosis. None of these patients had been exposed to phenothiazine drugs. The clinical syndrome described did not resemble kuru which is a subacute disease with prominent clinical signs indicating cerebellar dysfunction. Choreoathetotic movements occasionally occur in the terminal stages of the disease but evidence for dementia is usually absent until shortly before death. The presenile dementias like Alzheimer's disease are not typically accompanied by choreoathetosis.

It is of interest that the onset of clinical disease in these families tends to be earlier than in other series, with the exception of the Venezuelan study. ${ }^{6}$ Venezuela and New Britain lie close to the equator and perhaps some unknown factor or factors of the tropical environment play a part in the early expression of the disease.

The positive family history suggests that subjects IV.10 and IV.12 of family A represent juvenile cases of Huntington's disease. The clinical presentation of subject IV.12 in particular resembled the Westphal variant with the early development of rigidity, hypertonia, loss of facial expressive movements, hypokinesia, and dystonia. ${ }^{9}$ It is relevant that in juvenile cases the father is the affected parent three to four times more frequently than is the mother, and in addition there is a female sex preponderance in these cases. ${ }^{10}$

Although this is the first report of Huntington's disease in Papua New Guinea, there has been a previous report of the disease in Melanesians in the former British Solomon Islands Protectorate. ${ }^{11}$ It is possible that the aberrant gene arose by mutation or was introduced into this New Britain community long ago by some unknown person. The evidence for the former supposition may be considered. All known or potential cases have come from a very small area on the Gazelle Peninsula of New Britain (fig 2). The two principal coastal villages where most members of the two families are now located are 6 kilometres apart, equidistant from the original village where subject $I .1$ of both families are known to have lived. There is no recollection that any ancestors were foreigners. All members of both 




(a)

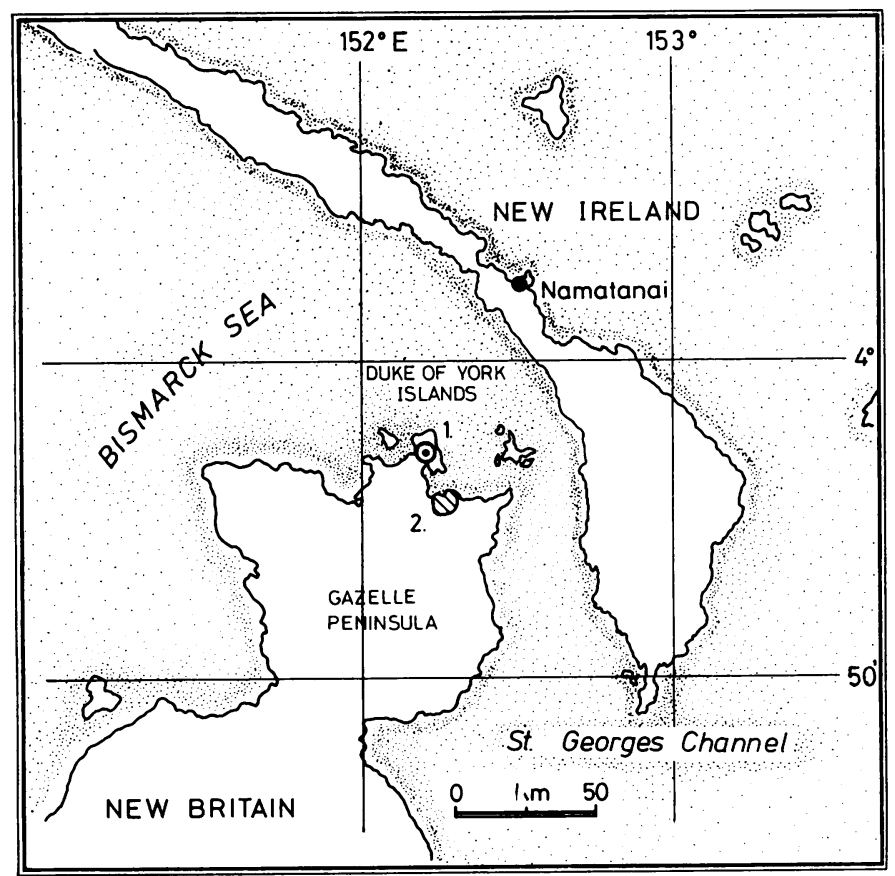

(b)

family groups appear to be Melanesian. Studies on blood groups show a distribution typical of Tolai gene frequencies in reported series. ${ }^{12}$ The presence of systems suggesting Caucasian genetic influence was not seen; for example the Kell system is not known to occur in Melanesians and was absent in the blood tested. However, the only certain proof of mutation in Huntington's disease, the demonstration
FIG 2 (a) Location of New Britain, Papua New Guinea. Boxed area enlarged below. (b) Gazelle Peninsula, East New Britain. 1, Rabaul; 2, original focus of Huntington's disease. of normal parentage in the preceding generation, is 0 not feasible in this community where family memory and written records do not provide information? before 1900. Mutation is in fact reported to be very 0 rare in this condition. In Michigan the mutation rate was calculated to be 1 in 200000 per generation. ${ }^{2}$

The strong possibility that the gene was introduced $\stackrel{\mathbb{Q}}{\propto}$ must therefore be entertained. The Gazelle Peninsula 
is not known to have been visited by Europeans until two traders arrived in $1873 .{ }^{13}$ As subject I.1 of family A was presumably born about 1860 , it is likely that if the abnormal gene was introduced it was brought into this community perhaps some years before that date. It is believed that the Tolai people originally came from the southern part of New Ireland to East New Britain in successive waves of migration starting some hundreds of years ago. Genetic and linguistic studies have confirmed that the Tolai and the people of southern New Ireland are closely related, and close ties are maintained to this day between these two groups. ${ }^{1415}$ The bearer of the abnormal gene may have come to the Gazelle Peninsula from New Ireland, and might well have been of mixed ancestry or a Melanesian female already pregnant from a marriage or liaison with the carrier of the aberrant gene. As a result of their position on the Sydney to Canton shipping route, New Ireland and, to a lesser extent, the Duke of York Islands off the coast of New Britain, were regularly visited by ships from the late 18th century to obtain fresh water and supplies. In addition there were extensive sperm whaling grounds off the east coast of New Ireland and it is known that American and Australian colonial whaling ships visited harbours on this coast and traded with the local people. ${ }^{16}$ The peak whaling years throughout the oceans of the world were 1820 to 1860 , and during this era the Americans dominated the industry. Major ports of origin of the American whalers included Nantucket, New London, and the acknowledged 'capital' New Bedford, Massachusetts. ${ }^{17}$ It is of interest that Huntington's disease is known to be relatively common in the New England states of the United States of America. ${ }^{18}$ Many seamen, particularly from whaling vessels, are known to have deserted and taken up residence in these islands. ${ }^{19}$ One may accept that on occasion, from the late 18th century, there must have been opportunities for the introduction of new genetic material into these island communities.

The high infant mortality rate and short life expectancy of former years has helped limit the incidence of the disease in this area. In addition, before the advent of Europeans to the Gazelle Peninsula, Tolai marriages tended to occur late and children were few in number. The reason that the disease has not come to the attention of medical officers before is presumably because of the small number of cases and because the families, believing sorcery to be involved, reasoned that modern medicine would have little to offer. Explanation of the disease is particularly difficult in this relatively unsophisticated and superstitious community. It is hoped that some of the younger members, who are now being educated, will understand the mode of inheritance and be induced to postpone or limit their families. It has been necessary to become friendly with the numerous family members in a gradual and unobtrusive way, and great care has been taken to avoid posing a threat in any way. On only one occasion in the initial days of this study 15 months ago have patients been asked to attend a hospital. Subsequently patients and relatives have always been visited in their own villages. Relatives of affected members are very sensitive and ashamed that the condition is in their lineage and one senses that the families involved tend to be ostracised. The affliction, while feared, is accepted stoically enough, at least on the surface, by patients and their families once it has become established. There is little or no rejection. Family ties are stronger than in the average Western society, and the patient is cared for in his village until the end. To date, no patient is known to have committed suicide. It is very improbable that a necropsy will be permitted in the near future and at present treatment has little to offer these patients. In Papua New Guinea, the only recommended drugs available are phenothiazines and isoniazid. ${ }^{20}$ Traditional medicine is widely practised in New Britain and patients and families continue to resort to 'bush medicine'.

The migration and present location of members of the families is indicated in the table. Further studies are required to determine the prevalence rates for this population. In order to facilitate further study and genetic counselling, a Huntington's Disease Register has been established according to the system devised by the Department of Human Genetics of the University of Michigan.

I would like to thank Professor Frank L Mastaglia, Professor of Experimental Neurology, Newcastle General Hospital for his interest in this study. Professor Mastaglia kindly reviewed films of patients and confirmed that the features demonstrated were typical of Huntington's disease. I would also like to acknowledge the invaluable help given by Mr Robert W Robin, Visiting Lecturer, Department of Psychology, University of Papua New Guinea, who made initial contact with family

TABLE Present location of members of the two families in the provinces of Papua New Guinea

\begin{tabular}{llc}
\hline & Affected subjects & Potential cases \\
\hline East New Britain & 5 & 35 \\
New Ireland & 2 & 6 \\
Bougainville & 1 & 6 \\
Morobe & & 1 \\
Central & & 1 \\
Eastern Highlands & & 1 \\
Total & 8 & 50 \\
\hline
\end{tabular}


B patients and provided psychological assessment of some of these patients. Dr Peter Banis of San Francisco, California, kindly provided a psychiatric appraisal of subjects III.17, 19, and 20 of family B. I would also like to thank Dr Michael Alpers, Director, Institute of Medical Research, Goroka, Papua New Guinea for his encouragement of this study. Finally I would like to thank Sylvia Scrimgeour for assisting in the field studies and for typing the manuscript.

\section{References}

1 Davenport CB, Muncey EB. Huntington's chorea in relation to heredity and eugenics. Am J Hum Genet 1916;73:195.

2 Reed TE, Neal JV. Huntington's chorea in Michigan (2). Selection and mutation. Am J Hum Genet 1959;11:107.

3 Bruyn GW. Huntington's chorea: historical, clinical and laboratory synopsis. In: Vinken PJ, Bruyn GW, eds. Handbook of clinical neurology. vol 6. Amsterdam: North Holland Publishing Co, 1968:312.

4 Bell J. Huntington's chorea. In: The treasury of human inheritance. vol 4, part 1. London: Cambridge University Press, 1934.

5 Cameron D, Venters GA. Some problems in Huntington's chorea. Scott Med J 1967;12:152.

- Negrete A. In: Corea de Huntington. Estudio de una sola familia investigada a traves de varias gene raciones. Maracaibo: Universidad de Zulia, 1962:221.

7 Reed TE, Chandler JN. Huntington's chorea in Michigan (1). Demography and genetics. Am J Hum Genet 1958; 10:201.

8 Heathfield KWG. Huntington's chorea: a centenary review. Postgrad Med J 1973;49:35.

9 Westphal ACO. Uber die diagnose der Huntingtonschen

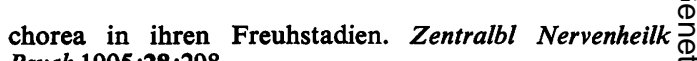
Psych 1905;28:298.

10 Bruyn GW. The Westphal variant in juvenile type of $\Rightarrow$ Huntington's chorea. In: Barbeau A, Brunette JR, eds. $\stackrel{\text { f }}{\rightarrow}$ Progress in neuro-genetics. Amsterdam: Excerpta Medica, 0 1967:666-73.

11 Hetherington HB, Wechszler Z. Huntington's chorea in a native Melanesian family of the British Solomon Islands. $\frac{7}{7}$ Med J Aust 1942;1:599-600.

12 Booth PB, Vines AP, Saave JJ. Further blood group genetic data from New Britain. In: Archaeology and $\infty$ physical anthropology in Oceania. vol 4:2. New South $\vec{O}$ Wales: University of Sydney, 1969:113-9.

13 Brown G. George Brown DD, pioneer missionary and $\overrightarrow{\vec{\omega}}$ explorer. An autobiography. London: Hodder and Stoughton, 1908:99.

14 Booth PB, Vines AP. Blood groups and other genetic data from the Bismarck Archipelago, New Guinea. In:Archaeology and physical anthropology in Oceania. vol 3. W 1968:64-72.

15 Capell A. A linguistic survey of the South-Western $\overrightarrow{0}$ Pacific. (SPC Technical Paper no 136). Noumea, New Caledonia: South Pacific Commission, 1962:37-41.

16 Gash N, Whittaker J. A pictorial history of New Guinea. Queensland: Jacaranda Press, 1975:26.

17 Graves W. The imperilled giants. National Geographic 1976;150:722-30.

18 Critchley M. Great Britain and the early history of Huntington's chorea. In: Advances in neurology. vol 1.c0 New York: Raven Press, 1973:14.

19 Despatches to Governor of New South Wales. January to June. (Mitchell Library: A 1282) 1840:825, 827.

20 Perry TL, Macleod PM, Hansen S. Treatment of Huntington's chorea with isoniazid. N Engl J Med 1977;297:840.

Requests for reprints to Dr E M Scrimgeour, Depart-这 ment of Clinical Sciences, Faculty of Medicine, $\overrightarrow{\vec{P}}$ Box 5623, Boroko, Papua New Guinea. 